\title{
EVALUASI PENGGUNAAN TERAPI ANTIHIPERTENSI PADA PASIEN GAGAL GINJAL KRONIK DENGAN HEMODIALISIS
}

\section{EVALUATION OF ANTIHYPERTENSIVE THERAPY IN CHRONIC KIDNEY DISEASE WITH HAEMODIALYSIS PATIENTS}

\author{
Nadia Husna ${ }^{1 *}$, Niken Larasati ${ }^{2}$ \\ ${ }^{* 1}$ Prodi Farmasi, Fakultas Kesehatan, Universitas Jenderal Achmad Yani Yogyakarta, Jl. Brawijaya \\ Ambarketawang Gamping Sleman Yogyakarta, email: nadia.husna118@gmail.com, Indonesia \\ ${ }^{2}$ Prodi Farmasi, Fakultas Kesehatan, Universitas Jenderal Achmad Yani Yogyakarta, Jl. Brawijaya \\ Ambarketawang Gamping Sleman Yogyakarta, email: mylaraslarashaty@gmail.com, Indonesia
}

\begin{abstract}
Background: End Stage Renal Disease (ESRD) occurs when Glomerular Filtration Rate (GFR) falls below $15 \mathrm{ml} /$ minute $/ 1.73 \mathrm{~m}^{2}$. This condition leads to Renal Replacement Therapy (RRT) intervention namely dialysis and kidney transplantation. The intervention inclines morbidity and hospitalization rate which means more physical and financial burden to patients as the consequences. One of the physical side effects that becomes a major cause of increasing cardiovasculer mortality is hypertension.

Objective: The purpose of this study was to analyze the rationale of antihypertensive therapy in haemodialysis patients.

Methods: A descriptive, purposive, non experimental study gathering medical records of 97 hemodialysis with antihypertensive therapy patients of PKU Muhammadiyah Gamping hospital who were admitted from June until August 2018 was held in this study.

Results: Majority of patients were female (63,92\%), aged between 41-75 years (83,50\%), and diagnosed with chronic kidney disease (CKD) $(95,58 \%)$, received three combination of antihypertensive drugs $(38,14 \%)$ using Calcium Channel Blocker namely amlodipin (20,86\%). The analysis of antihypertensive therapy including accurate drugs, patients, and dosage were $83,51 \%, 100 \%$, and $97,72 \%$ respectively.

Conclusion: The use of antihypertensive drugs in CKD patient in PKU Muhammadiyah Gamping was approprite
\end{abstract}

Keywords: Antihypertension, chronic kidney disease, evaluation, hemodialysis, hospital.

\section{PENDAHULUAN}

Gagal ginjal kronik didefinisikan sebagai abnormalitas yang terjadi pada struktur atau fungsi ginjal, terjadi selama 3 bulan atau lebih yang memberikan implikasi pada kesehatan. Gagal ginjal kronik atau Penyakit Ginjal Kronik (PGK) stage 5 juga disebut End Stage Renal Disease (ESRD) terjadi ketika nilai GFR berada dibawah 15 $\mathrm{ml} /$ menit/1,73m ${ }^{2}{ }^{1} \quad$ Bertambahnya insidensi ESRD berdampak pada meningkatnya penggunaan terapi pengganti ginjal atau Renal Replacement Therapy (RRT). Terdapat 2 macam RRT yaitu dialisis dan transplantasi ginjal. Intervensi dialisis memunculkan beberapa komplikasi seperti hipotensi, kram, mual muntah, nyeri kepala, nyeri dada, nyeri punggung, dan gatal-gatal. Target tekanan darah pada pasien hipertensi dengan penyakit ginjal sebagai faktor penyulit disarankan $<140 / 90 \mathrm{mmHg}^{2}$

Pencapaian target tekanan darah ini menjadi tantangan yang berat untuk dicapai mengingat kondisi hipertensi yang tidak terkontrol merupakan faktor risiko terjadinya komplikasi kardiovaskular yang memengaruhi morbiditas dan mortalitas pasien dengan hemodialisis kronis. $^{3}$ Kondisi inilah yang 
menjadi landasan dasar pentingnya pemberian antihipertensi pasien dengan hemodialisis. ${ }^{4}$ Tujuan penelitian ini adalah mengevaluasi penggunaan atau rasionalitas penggunaan antihipertensi pada pasien hemodialisis.

\section{BAHAN DAN CARA PENELITIAN}

Penelitian ini merupakan penelitian retrospektif dengan metode deskriptif non eksperimental. Teknik pengambilan sampel menggunakan non random dengan cara consecutive sampling. Objek penelitian ini adalah pasien hemodialisis dengan terapi antihipertensi berjumlah 97 orang. Penelitian dilakukan di Rumah Sakit PKU Muhammadiyah Gamping Yogyakarta pada Bulan Juni hingga Agustus 2018. Alat ukur penelitian menggunakan rekapan data penelitian yang memuat karakteristik pasien dan pengobatannya.

Jalannya penelitian dibagi menjadi dua yaitu tahap awal dan tahap penelitian. Pada tahap awal dilakukan pembuatan proposal, persiapan dengan mengurus perizinan serta observasi. Observasi dilakukan untuk menentukan jumlah responden dan mencatat nomor rekam medik pasien. Pada tahap penelitian peneliti mengumpulkan data karakteristik dan pengobatan pasien menggunakan lembar pengumpulan data. Data karakteristik dan pengobatan pasien dianalisis secara deskriptif. Data terapi obat pasien disesuaikan dengan British National
Formulary 61 (2011) dan Drug Information Handbook 19th Edition (2010) untuk analisis tepat pasien, indikasi, kontra indikasi, dan frekuensi pemberian, $8^{\text {th }}$ Joint National Committee of Hypertension (2013) dan Phamacoterapy Handbook $9^{\text {th }}$ Edition (2015) untuk analisis tepat obat, dan Drug Dosing Renal Failure (2000) serta Drug Information Handbook $19^{\text {th }}$ Edition (2010) untuk analisis tepat dosis.

\section{HASIL DAN PEMBAHASAN}

Karakteristik pasien yang disajikan dalam data adalah jenis kelamin, umur, dan diagnosis, serta riwayat penyakit. Data ini dianalisis secara deskriptif.

Tabel 1. Karakteristik Responden (N=97)

\begin{tabular}{|c|c|c|}
\hline & Karakteristik & Frek (\%) \\
\hline \multirow{2}{*}{$\begin{array}{l}\text { Jenis } \\
\text { Kelamin }\end{array}$} & Laki-laki & $62(63,92)$ \\
\hline & Perempuan & $35(36,46)$ \\
\hline \multirow[t]{3}{*}{ Usia } & 18-40 tahun & $14(14,43)$ \\
\hline & 41-75 tahun & $81(83,50)$ \\
\hline & $>75$ tahun & $2(2,06)$ \\
\hline \multirow{5}{*}{$\begin{array}{l}\text { Diagnosis } \\
\text { dan } \\
\text { riwayat } \\
\text { penyakit }\end{array}$} & $\begin{array}{l}\text { Gagal ginjal kronik } \\
\text { (GGK) }\end{array}$ & $93(95,88)$ \\
\hline & GGK dan Hipertensi & $1(1,03)$ \\
\hline & $\begin{array}{l}\text { GGK dan Diabetes } \\
\text { Melitus }\end{array}$ & $1(1,03)$ \\
\hline & $\begin{array}{l}\text { GGK, Hipertensi, dan } \\
\text { Diabetes Melitus }\end{array}$ & $1(1,03)$ \\
\hline & $\begin{array}{l}\text { GGK, Hipertensi, } \\
\text { Diabetes Melitus, dan } \\
\text { Pneumonia }\end{array}$ & $1(1,03)$ \\
\hline
\end{tabular}

Berdasarkan tabel 1 jumlah pasien laki-laki penderita hipertensi dengan hemodialisis lebih banyak dengan jumlah 62 orang $(63,92 \%)$ dibandingkan dengan pasien perempuan dengan jumlah 35 orang $(36,46 \%)$. Hal ini sesuai dengan penelitian yang menyebutkan bahwa persentase jenis 
kelamin pasien hemodialisis pada laki-laki sebesar $74 \%$ dan $52,8 \% .^{5}$ Usia pasien penderita hemodialisis terbanyak pada rentang usia $41-75$ tahun $(83,50 \%)$. Hal ini dikarenakan semakin bertambahnya usia maka fungsi organ tubuh akan semakin menurun sehingga fungsi pembuluh darah dan ginjal akan semakin kehilangan keelastisannya dalam memodulasi tekanan darah. Diagnosa dan riwayat penyakit pasien menurut data hasil adalah gagal ginjal kronik, gagal ginjal kronik dan hipertensi, gagal ginjal kronik dan diabetes melitus, gagal ginjal kronik, hipertensi, dan diabetes melitus, serta gagal ginjal kronik, hipertensi, diabetes melitus, dan penumonia.

Agen antihipertensi yang digunakan sesuai dengan pedoman Joint National Committee of Hypertension VIII tahun 2014. Jumlah antihipertensi yang digunakan adalah tunggal dan kombinasi. Pada tabel 2 didapatkan data penggunaan obat antihipertensi pada pasien hemodialisis di Rumah Sakit PKU Muhammadiyah Gamping paling banyak menggunakan 3 kombinasi $(39,18 \%)$. Studi yang dilakukan menunjukkan data sebanyak $46 \%$ pasien hipertensi dengan gagal ginjal kronik mendapatkan terapi kombinasi dari dua obat. ${ }^{6}$ Penggunaan kombinasi obat bertujuan untuk mempertahankan tekanan darah menggunakan dua antihipertensi yang memiliki tempat aksi dan golongan yang berbeda dan untuk meningkatkan kepatuhan pasien dengan menggunakan satu tablet yang diminum dua atau tiga kali sehari.

\section{Golongan Calcium Channel Blocker} menjadi golongan antihipertensi yang paling banyak digunakan dengan jumlah 29,14\% dan obat yang paling banyak digunakan dalam golongan ini adalah amlodipin sebesar 20,86\%. Calcium Channel Blocker golongan dihidropiridin digunakan secara luas pada pasien hipertensi dengan hemodialisis untuk menurunkan tekanan darah. Sebuah studi acak mengatakan bahwa amlodipin menurunkan tekanan darah secara signifikan pada pasien hipertensi dengan hemodialisis yang dibandingkan dengan pemberian plasebo. ${ }^{7}$ Penggunaan golongan Calcium Channel Blocker telah ditunjukkan pada data penelitian di RSUP Prof. Dr. R. D. Kandou Manado sebanyak 58,3\%. ${ }^{5}$ Mekanisme kerja golongan Calcium Channel Blocker adalah menghambat masuknya kalsium ke dalam otot polos pembuluh darah sehingga mengurangi tahanan perifer. ${ }^{8}$

Tabel 2. Distribusi Karakteristik Antihipertensi Pada Pasien Hemodialisis di Rumah Sakit PKU Muhammadiyah Gamping

\begin{tabular}{|c|c|c|c|c|}
\hline \multicolumn{2}{|c|}{ Karakteristik } & \multirow{2}{*}{$\begin{array}{c}\mathbf{n}(\%) \\
9(9,28) \\
\end{array}$} & \multirow{2}{*}{$\begin{array}{c}\text { Nama } \\
\text { Obat }\end{array}$} & \multirow[t]{2}{*}{ n (\%) } \\
\hline Jumlah & Tunggal & & & \\
\hline Obat & $\begin{array}{l}2 \\
\text { Kombin } \\
\text { asi }\end{array}$ & $\begin{array}{c}17 \\
(17,53)\end{array}$ & & \\
\hline & $\begin{array}{l}3 \\
\text { Kombin } \\
\text { asi }\end{array}$ & $\begin{array}{c}37 \\
(38,14)\end{array}$ & & \\
\hline & $\begin{array}{l}4 \\
\text { Kombin } \\
\text { asi }\end{array}$ & $\begin{array}{c}23 \\
(23,71)\end{array}$ & & \\
\hline & $\begin{array}{l}5 \\
\text { Kombin } \\
\text { asi }\end{array}$ & $\begin{array}{c}10 \\
(10,31)\end{array}$ & & \\
\hline & 6 & $1(1,03)$ & & \\
\hline
\end{tabular}




\begin{tabular}{|c|c|c|c|c|}
\hline Kara & $\begin{array}{l}\text { eristik } \\
\text { Kombin } \\
\text { asi }\end{array}$ & n (\%) & $\begin{array}{c}\text { Nama } \\
\text { Obat }\end{array}$ & n (\%) \\
\hline \multirow[t]{13}{*}{$\begin{array}{l}\text { Golong } \\
\text { an }\end{array}$} & \multirow{2}{*}{$\begin{array}{l}\text { Angiote } \\
\text { nsin } \\
\text { Converti } \\
\text { ng } \\
\text { Enzyme } \\
\text { Inhibitor } \\
\text { (ACEI) }\end{array}$} & \multirow[t]{2}{*}{$7(2,32)$} & Captopril & $\begin{array}{c}5 \\
(1,66) \\
\end{array}$ \\
\hline & & & Lisinopril & $\begin{array}{c}2 \\
(0,66)\end{array}$ \\
\hline & $\begin{array}{l}\text { Angiote } \\
n \sin \end{array}$ & $\begin{array}{c}80 \\
(26,49)\end{array}$ & $\begin{array}{l}\text { Candesart } \\
\text { an }\end{array}$ & $\begin{array}{c}24 \\
(7,95) \\
\end{array}$ \\
\hline & $\begin{array}{l}\text { Recepto } \\
r \\
\text { Blocker } \\
\text { (ARB) } \\
\end{array}$ & & Irbesartan & $\begin{array}{c}56 \\
(18, \\
54)\end{array}$ \\
\hline & $\begin{array}{l}\text { Beta } \\
\text { Blocker } \\
\text { (BB) }\end{array}$ & $\begin{array}{c}33 \\
(10,93)\end{array}$ & Bisoprolol & $\begin{array}{c}33 \\
(10, \\
93)\end{array}$ \\
\hline & \multirow{3}{*}{$\begin{array}{l}\text { Calcium } \\
\text { Channel } \\
\text { Blocker } \\
\text { (CCB) }\end{array}$} & \multirow[t]{3}{*}{$\begin{array}{c}88 \\
(29,14)\end{array}$} & Amlodipin & $\begin{array}{c}63 \\
(20,8 \\
6) \\
\end{array}$ \\
\hline & & & Nifedipin & $\begin{array}{c}16 \\
(5,30) \\
\end{array}$ \\
\hline & & & Diltiazem & $\begin{array}{c}9 \\
(2,98) \\
\end{array}$ \\
\hline & $\begin{array}{l}\text { Central } \\
\text { acting }\end{array}$ & $\begin{array}{c}28 \\
(9,27)\end{array}$ & Clonidin & $\begin{array}{c}28 \\
(9,27)\end{array}$ \\
\hline & \multirow[t]{2}{*}{ Diuretik } & $\begin{array}{c}62 \\
(20,53)\end{array}$ & Furosemid & $\begin{array}{c}60 \\
(19,8 \\
7) \\
\end{array}$ \\
\hline & & & $\begin{array}{l}\text { Hidroklorti } \\
\text { azid }\end{array}$ & $\begin{array}{c}2 \\
(0,66)\end{array}$ \\
\hline & \multirow[t]{2}{*}{$\begin{array}{l}\text { Vasodila } \\
\text { tor }\end{array}$} & \multirow[t]{2}{*}{$4(1,32)$} & $\begin{array}{l}\text { Gliseril } \\
\text { trinitrat }\end{array}$ & $\begin{array}{c}1 \\
(0,33) \\
\end{array}$ \\
\hline & & & $\begin{array}{l}\text { Isosorbid } \\
\text { dinitrat }\end{array}$ & $\begin{array}{c}3 \\
(0,99)\end{array}$ \\
\hline
\end{tabular}

Berdasarkan tabel 3 penggunaan obat yang tepat sesuai dengan kondisi pasien adalah sebanyak 97 pasien (100\%). Hal ini sudah sesuai berdasarkan panduan Joint National Committee of Hypertension VIII tahun 2014 yang menyatakan bahwa pengobatan pada pasien hipertensi dengan gagal ginjal kronik untuk segala umur menggunakan agen Angiotensin Converting Enzyme Inhibitor (ACEI) atau Angiotensin
Receptor Blocker (ARB) dan kemudian dapat dikombinasikan dengan agen lain yang disesuaikan dengan kondisi pasien.

Pemilihan obat yang tepat akan mengoptimalkan pengobatan pasien. Pemilihan obat didasarkan pada diagnosis dan riwayat penyakit pasien. Tabel 3 menunjukkan pengobatan pada 81 pasien $(83,51 \%)$ sudah tepat artinya pemberian ini sudah sesuai dengan diagnosa dan riwayat penyakit pasien. Tabel yang sama menunjukkan beberapa obat tidak tepat pengobatan contohnya adalah amlodipin, nifedipin, bisoprolol, clonidin, dan furosemid. Hal ini dikarenakan obat-obat tersebut bukan merupakan first line therapy pada pasien hipertensi dengan hemodialisis.

Tabel 3. Evaluasi Tepat Obat Antihipertensi dan Tepat Pasien Hemodialisis Di Rumah Sakit PKU Muhammadiyah Gamping

\begin{tabular}{|c|c|c|c|}
\hline \multirow[t]{2}{*}{ Jenis Obat } & \multicolumn{2}{|c|}{$\begin{array}{c}\text { Ketepatan } \\
\text { Obat }\end{array}$} & $\begin{array}{l}\text { Ketepatan } \\
\text { Pasien }\end{array}$ \\
\hline & $\begin{array}{l}\text { Te- } \\
\text { pat }\end{array}$ & $\begin{array}{l}\text { Tidak } \\
\text { tepat }\end{array}$ & $\begin{array}{ll}\text { Te- } & \text { Tidak } \\
\text { pat } & \text { tepat }\end{array}$ \\
\hline Amlodipin & & 1 & 1 \\
\hline Candesartan & 3 & & 1 \\
\hline Irbesartan & 3 & & 1 \\
\hline Furosemid & & 3 & 1 \\
\hline Amlodipin, Clonidin & & 1 & 1 \\
\hline $\begin{array}{l}\text { Amlodipin, } \\
\text { Furosemid }\end{array}$ & & 2 & 1 \\
\hline $\begin{array}{l}\text { Amlodipin, } \\
\text { Captopril }\end{array}$ & 1 & & 1 \\
\hline $\begin{array}{l}\text { Amlodipin, } \\
\text { Candesartan }\end{array}$ & 1 & & 1 \\
\hline $\begin{array}{l}\text { Amlodipin, } \\
\text { Irbesartan }\end{array}$ & 3 & & 1 \\
\hline $\begin{array}{l}\text { Bisoprolol, } \\
\text { Nifedipin }\end{array}$ & & 1 & 1 \\
\hline $\begin{array}{l}\text { Diltiazem, } \\
\text { Irbesartan }\end{array}$ & 1 & & 1 \\
\hline
\end{tabular}


Media Ilmu Kesehatan Vol. 8, No. 1, April 2019

\begin{tabular}{|c|c|c|c|c|}
\hline \multirow[t]{2}{*}{ Jenis Obat } & \multicolumn{2}{|c|}{$\begin{array}{c}\text { Ketepatan } \\
\text { Obat }\end{array}$} & \multicolumn{2}{|c|}{$\begin{array}{c}\text { Ketepatan } \\
\text { Pasien }\end{array}$} \\
\hline & $\begin{array}{l}\text { Te- } \\
\text { pat }\end{array}$ & $\begin{array}{l}\text { Tidak } \\
\text { tepat }\end{array}$ & $\begin{array}{l}\text { Te- } \\
\text { pat }\end{array}$ & $\begin{array}{l}\text { Tidak } \\
\text { tepat }\end{array}$ \\
\hline $\begin{array}{l}\text { Furosemid, } \\
\text { Irbesartan }\end{array}$ & 4 & & 1 & \\
\hline $\begin{array}{l}\text { Furosemid,Nifedipi } \\
\mathrm{n}\end{array}$ & & 1 & 1 & \\
\hline $\begin{array}{l}\text { Irbesartan, } \\
\text { Nifedipin }\end{array}$ & 1 & & 1 & \\
\hline $\begin{array}{l}\text { Amlodipin, } \\
\text { Bisoprolol, } \\
\text { Candesartan } \\
\end{array}$ & 1 & & 1 & \\
\hline $\begin{array}{l}\text { Amlodipin, } \\
\text { Irbesartan, } \\
\text { Bisoprolol } \\
\end{array}$ & 7 & & 1 & \\
\hline $\begin{array}{l}\text { Amlodipin, } \\
\text { Bisoprolol, Clonidin }\end{array}$ & & 2 & 1 & \\
\hline $\begin{array}{l}\text { Amlodipin, } \\
\text { Candesartan, } \\
\text { Furosemid } \\
\end{array}$ & 5 & & 1 & \\
\hline $\begin{array}{l}\text { Amlodipin, } \\
\text { Furosemid, } \\
\text { Irbesartan } \\
\end{array}$ & 12 & & 1 & \\
\hline $\begin{array}{l}\text { Bisoprolol, } \\
\text { Clonidin, Irbesartan }\end{array}$ & 1 & & 1 & \\
\hline $\begin{array}{l}\text { Candesartan, } \\
\text { Furosemid, } \\
\text { Nifedipin } \\
\end{array}$ & 1 & & 1 & \\
\hline $\begin{array}{l}\text { Candesartan, } \\
\text { Nifedipin, Gliseril } \\
\text { Trinitrat } \\
\end{array}$ & 1 & & 1 & \\
\hline $\begin{array}{l}\text { Candesartan, } \\
\text { Bisoprolol, } \\
\text { Furosemid } \\
\end{array}$ & 1 & & 1 & \\
\hline $\begin{array}{l}\text { Furosemid, } \\
\text { Irbesartan, } \\
\text { Nifedipin }\end{array}$ & 1 & & 1 & \\
\hline $\begin{array}{l}\text { Amlodipin, } \\
\text { Furosemid, } \\
\text { Irbesartan }\end{array}$ & 2 & & 1 & \\
\hline $\begin{array}{l}\text { Captopril, } \\
\text { Irbesartan, } \\
\text { Diltiazem, Clonidin }\end{array}$ & 1 & & 1 & \\
\hline $\begin{array}{l}\text { Captopril, } \\
\text { Nifedipin, } \\
\text { Bisoprolol, Clonidin }\end{array}$ & 1 & & 1 & \\
\hline $\begin{array}{l}\text { Candesartan, } \\
\text { Diltiazem, } \\
\text { Furosemid }\end{array}$ & 1 & & 1 & \\
\hline $\begin{array}{l}\text { Clonidin, } \\
\text { Furosemid, } \\
\text { Nifedipin }\end{array}$ & 1 & & 1 & \\
\hline $\begin{array}{l}\text { Amlodipin, } \\
\text { Clonidin, } \\
\text { Furosemid, }\end{array}$ & & 1 & 1 & \\
\hline
\end{tabular}

\begin{tabular}{|c|c|c|}
\hline Jenis Obat & $\begin{array}{c}\text { Ketepatan } \\
\text { Obat }\end{array}$ & $\begin{array}{c}\text { Ketepatan } \\
\text { Pasien }\end{array}$ \\
\hline & $\begin{array}{ll}\text { Te- } & \text { Tidak } \\
\text { pat } & \text { tepat }\end{array}$ & $\begin{array}{ll}\text { Te- } & \text { Tidak } \\
\text { pat } & \text { tepat }\end{array}$ \\
\hline
\end{tabular}

Nifedipin

Amlodipin,

Bisoprolol,

Clonidin, Irbesartan

Amlodipin,

Furosemid,

Clonidin, Irbesartan

Amlodipin,

Nifedipin,

Furosemid,

Clonidin

Amlodipin,

Candesartan,

Furosemid,

Isosorbid Dinitrat

Amlodipin,

Bisoprolol,

Candesartan,

Furosemid

Amlodipin,

Bisoprolol,

Candesartan,

Isosorbid

Amlodipin,

Bisoprolol,

Diltiazem,

Irbesartan

Amlodipin,

Candesartan,

Furosemid,

Nifedipin

Amlodipin,

Bisoprolol,

Furosemid,

Irbesartan

Irbesartan,

Diltiazem

Bisoprolol,

Furosemid

Clonidin, Diltiazem, 1

Furosemid,

Lisinopril

Clonidin,

Furosemid,

Irbesartan,

Nifedipin

Irbesartan,

Nifedipin,

Diltiazem,

Furosemid

Amlodipin,

4

$5-1$

1

1

2

1

1




\begin{tabular}{|c|c|c|c|c|}
\hline \multirow[t]{2}{*}{ Jenis Obat } & \multicolumn{2}{|c|}{$\begin{array}{c}\text { Ketepatan } \\
\text { Obat }\end{array}$} & \multicolumn{2}{|c|}{$\begin{array}{c}\text { Ketepatan } \\
\text { Pasien }\end{array}$} \\
\hline & $\begin{array}{l}\text { Te- } \\
\text { pat }\end{array}$ & $\begin{array}{l}\text { Tidak } \\
\text { tepat }\end{array}$ & $\begin{array}{l}\text { Te- } \\
\text { pat }\end{array}$ & $\begin{array}{l}\text { Tidak } \\
\text { tepat }\end{array}$ \\
\hline $\begin{array}{l}\text { Captopril,Clonidin, } \\
\text { Furosemid, } \\
\text { Irbesartan }\end{array}$ & & & & \\
\hline $\begin{array}{l}\text { Amlodipin, } \\
\text { Bisoprolol, } \\
\text { Clonidin, } \\
\text { Furosemid, } \\
\text { Irbesartan } \\
\end{array}$ & 4 & & 1 & \\
\hline $\begin{array}{l}\text { Amlodipin, } \\
\text { Bisoprolol, } \\
\text { Candesartan, } \\
\text { Clonidin, Nifedipin }\end{array}$ & & 1 & 1 & \\
\hline $\begin{array}{l}\text { Amlodipin, } \\
\text { Candesartan, } \\
\text { Furosemid, } \\
\text { Lisinopril, Nifedipin }\end{array}$ & & 1 & 1 & \\
\hline $\begin{array}{l}\text { Amlodipin, } \\
\text { Bisoprolol, } \\
\text { Candesartan, } \\
\text { Clonidin, } \\
\text { Furosemid }\end{array}$ & 1 & & 1 & \\
\hline $\begin{array}{l}\text { Bisoprolol, } \\
\text { Candesartan, } \\
\text { Furosemid,, } \\
\text { Isosorbid Dinitrat }\end{array}$ & 1 & & 1 & \\
\hline $\begin{array}{l}\text { Bisoprolol, } \\
\text { Clonidin, Diltiazem, } \\
\text { Hidroklortazid, } \\
\text { Irbesartan }\end{array}$ & 1 & & 1 & \\
\hline $\begin{array}{l}\text { Candesartan, } \\
\text { Nifedipin, } \\
\text { Bisoprolol, } \\
\text { Hidroklortiazid, } \\
\text { Furosemid, } \\
\text { Clonidin } \\
\end{array}$ & 1 & & 1 & \\
\hline $\mathrm{n}(\%)$ & $\begin{array}{r}81 \\
(83, \\
51) \\
\end{array}$ & $\begin{array}{c}16 \\
(16,49)\end{array}$ & $\begin{array}{c}97( \\
100 \\
) \\
\end{array}$ & $0(0)$ \\
\hline
\end{tabular}

Pengoptimalan pengobatan pada

pasien dapat dicapai dengan pemberian dosis yang sesuai. Pemberian dosis yang tepat didasarkan pada kondisi pasien yang mengalami hemodialisis. Pada hemodialisis, ginjal pasien mengalami penurunan fungsi sehingga dosis obat membutuhkan penyesuaian. Berdasarkan tabel 4 sebanyak
$91,72 \%$ pengobatan sudah sesuai dengan dosis yang dianjurkan.

Amlodipin sebanyak 9 obat tidak tepat dosis karena dosis yang diberikan lebih besar $(20 \mathrm{mg}$ ) dari dosis maksimal yang dianjurkan di mana dosis maksimal sehari yang dianjurkan adalah $10 \mathrm{mg}$. Dosis diltiazem yang dianjurkan adalah 180-420 mg per hari. ${ }^{9}$ Pada data terapi pasien diberikan dosis yang jauh lebih rendah yaitu 3-100 mg per hari. Penurunan dosis yang signfikan ini dapat diakibatkan karena kondisi ginjal pasien yang tidak normal karena pasien mengalami gagal ginjal kronik sehingga dosis diltiazem disesuaikan dengan kondisi ginjal pasien. Irbesartan memiliki dosis rekomendasi $150-300 \mathrm{mg}$ per hari sehingga pada data pasien hemodialisis pasien yang mendapat terapi diltiazem sebesar $600 \mathrm{mg}$ per hari sehingga dosis yang diberikan berlebih. Kelebihan dosis ini dapat meningkatkan efek samping diltiazem antara lain edema pembuluh darah dan nyeri kepala (10-20\%). ${ }^{9}$

Tabel 4. Evaluasi Tepat Dosis Antihipertensi

Pada Pasien Hemodialisis Di Rumah Sakit

PKU Muhammadiyah Gamping Yogyakarta

\begin{tabular}{lcccc}
\hline Nama Obat & \multicolumn{2}{c}{$\begin{array}{c}\text { Dosis }(\mathbf{m g}) \\
1 \times\end{array}$} & $\begin{array}{c}\text { Tepat } \\
\text { dosis }\end{array}$ & $\begin{array}{c}\text { Tidak } \\
\text { tepat } \\
\text { dosis }\end{array}$ \\
\hline Amlodipin & 10 & 10 & 43 & \\
\hline Amlodipin & 5 & 5 & 8 & \\
\hline Amlodipin & 10 & 20 & & 9 \\
\hline Amlodipin & 5 & 10 & 2 & \\
\hline
\end{tabular}




\begin{tabular}{|c|c|c|c|c|}
\hline \multirow[t]{2}{*}{ Nama Obat } & \multicolumn{2}{|c|}{ Dosis (mg) } & \multirow{2}{*}{$\begin{array}{l}\text { Tepat } \\
\text { dosis }\end{array}$} & \multirow{2}{*}{$\begin{array}{l}\text { Tidak } \\
\text { tepat } \\
\text { dosis }\end{array}$} \\
\hline & $1 x$ & $\begin{array}{c}1 \\
\text { hari }\end{array}$ & & \\
\hline Bisoprolol & 2,5 & 2,5 & 4 & \\
\hline Bisoprolol & 5 & 5 & 28 & \\
\hline Bisoprolol & 15 & 15 & 1 & \\
\hline Candesartan & 8 & 8 & 1 & \\
\hline Candesartan & 8 & 16 & 1 & \\
\hline Candesartan & 16 & 16 & 18 & \\
\hline Candesartan & 16 & 32 & 3 & \\
\hline Captopril & 12,5 & 12,5 & 1 & \\
\hline Captopril & 12,5 & 25 & 2 & \\
\hline Captopril & 50 & 100 & 3 & \\
\hline Clonidin & 0,5 & 1 & 5 & \\
\hline Clonidin & 0,15 & 0,3 & 22 & \\
\hline Clonidin & 0,15 & 0,3 & 1 & \\
\hline Diltiazem & 30 & 30 & & 1 \\
\hline Diltiazem & $\begin{array}{l}30 \\
\mathrm{~m}\end{array}$ & 90 & & 2 \\
\hline Diltiazem & 100 & 100 & & 5 \\
\hline Diltiazem & 100 & 300 & 1 & \\
\hline Furosemid & 40 & 40 & 34 & \\
\hline Furosemid & 40 & 80 & 26 & \\
\hline Furosemid & 40 & 120 & 1 & \\
\hline $\begin{array}{l}\text { Gliseril } \\
\text { trinitrat }\end{array}$ & 2,5 & 5 & 1 & \\
\hline $\begin{array}{l}\text { Hidroklortiaz } \\
\text { id }\end{array}$ & 25 & 25 & 2 & \\
\hline Irbesartan & 200 & 200 & 1 & \\
\hline Irbesartan & 300 & 300 & 35 & \\
\hline Irbesartan & 150 & 150 & 12 & \\
\hline Irbesartan & 300 & 600 & & 8 \\
\hline Isosorbid & 5 & 5 & 3 & \\
\hline Lisinopril & 10 & 10 & 5 & \\
\hline Nifedipin & 10 & 30 & 4 & \\
\hline Nifedipin & 30 & 30 & 9 & \\
\hline $\mathrm{n}(\%)$ & & & $\begin{array}{c}277(91,7 \\
2) \\
\end{array}$ & $\begin{array}{c}25 \\
(8,28) \\
\end{array}$ \\
\hline
\end{tabular}

\section{KESIMPULAN}

Penggunaan antihipertensi pada pasien gagal ginjal kronik dengan hemodialisa di Rumah Sakit PKU Muhammadiyah Gamping sudah rasional dengan rincian tepat obat $83,51 \%$, tepat pasien $100 \%$, dan tepat dosis $91,72 \%$.

\section{TERIMA KASIH}

1. Kuswanto Hadjo, dr., M.Kes, Dekan Fakultas Kesehatan Universitas Jenderal Achmad Yani Yogyakarta, email: info@stikesayaniyk.ac.id.

2. Deby Zulkarnain R.S,S.Kep., Ns., MMR, Ketua PPPM Fakultas Kesehatan Universitas Jenderal Achmad Yani Yogyakarta, 0274 4342000, email: pppm@unjaya.ac.id

\section{KEPUSTAKAAN}

1. Dipiro T, et al.Pharmacotherapy Handbook $9^{\text {th }}$ Edition. 2015.McGrawHill Education.

2. $8^{\text {th }}$ Joint National Committee of Hypertension.JNC 8 Guidelines Algorithm. 2013.

3. Agarwal, et al.Prevalence, Treatment, And Control Of Hypertension In Chronic Hemodialysis Patients In United States. 2003. Am J Med.

4. National Kidney Foundation.K/DOQI Clinical Practice Guidelines for Cardiovascular Disease in Dialysis Patients. 2005.

5. Muchtar, dkk. Studi Penggunaan Obat Antihipertensi Pada Pasien Gagal Ginjal Kronik Yang Menjalani Perawatan Di Rsup Prof. Dr. R. D. Kandou Manado Periode Juli 2013 - Juni 2014. Jurnal IImiah Farmasi. Vol. 4 No. 3 Agustus 2015 ISSN 2302 - 2493.

6. Priyadi, dkk. Evaluasi Penggunaan Obat Antihipertensi Pada Pasien Gagal Ginjal 
Kronik Di Salah Satu Rumah Sakit

Swasta Di Kota Bandung. Prosiding

Rakernas dan Pertemuan IImiah

Tahunan Ikatan Apoteker Indonesia.

2016. e-ISSN : 2541-0474.

7. Yoshihiro, Taniyama.Management of Hypertension For Patients Undergoing Dialysis Therapy. 2016. Renal Replacement Therapy.

8. Gormer, Beth. 2007. terj. Diana Lyrawati, 2008.Farmakologi Hipertensi lyrawati.files.wordpress.com.

9. Lacy, dkk. Drug Information Handbook $19^{\text {th }}$ Edition. American Pharmacist's Asociation. Lexi-comp. 2010. 